\title{
Identification of differentially expressed transcripts targeted by the knockdown of endogenous IFITM3
}

\author{
CHEN SHEN, YING-JIA LI, QING-QIN YIN, WEI-WEI JIAO, QIN-JING LI, JING XIAO, \\ LIN SUN, FANG XU, JIE-QIONG LI, HUI QI and A-DONG SHEN

\begin{abstract}
Key Laboratory of Major Diseases in Children, Ministry of Education, National Key Discipline of Pediatrics, National Clinical Research Center for Respiratory Diseases,

Beijing Key Laboratory of Pediatric Respiratory Infection Diseases, Beijing Pediatric Research Institute, Beijing Children's Hospital, Capital Medical University, Beijing 100045, P.R. China
\end{abstract}

Received August 28, 2015; Accepted August 24, 2016

DOI: $10.3892 / \mathrm{mmr} .2016 .5777$

\begin{abstract}
Interferon inducible transmembrane protein 3 (IFITM3) is a double transmembrane protein. As a member of the IFITM family, IFITM3 can be upregulated by interferon (IFN) to be involved in various biological processes. In order to determine whether gene expression profiles can be altered by a lack of IFITM3, the present study used shRNAs lentivirus for knocking down the endogenous expression of IFITM3 in human HeLa cells and human whole genome microarrays to obtain gene expression profiles. A total of 1,011 downregulated transcripts and 615 upregulated transcripts were identified using the Agilent expression platform. The identified transcripts were involved in multiple pathways, including the complement pathways, and the antigen processing and presentation pathway. The present study identified the transcripts, which were affected by the downregulation of endogenous IFITM 3 and the pathways they were involved in. These findings may lead to an improved understanding of the biological functions of IFITM3.
\end{abstract}

\section{Introduction}

Interferon-induced transmembrane protein 3 (IFITM3) is a member of the gene family encoding IFITM, which can be upregulated by type I IFN (IFN- $\alpha$ and IFN- $\beta$ ) and type II IFN (IFN- $\gamma)$. In humans, the IFITM gene family comprises at least

Correspondence to: Professor A-Dong Shen, Key Laboratory of Major Diseases in Children, Ministry of Education, National Key Discipline of Pediatrics, National Clinical Research Center for Respiratory Diseases, Beijing Key Laboratory of Pediatric Respiratory Infection Diseases, Beijing Pediatric Research Institute, Beijing Children's Hospital, Capital Medical University, 56 Nanlishi Road, Xicheng, Beijing 100045, P.R. China

E-mail: shenad16@hotmail.com

Key words: interferon inducible transmembrane protein 3, gene knock down, transcription four members, termed IFITM1, IFITM2, IFITM3 and IFITM5, respectively (1). The IFITM genes are clustered on chromosome 11, encoding for proteins upregulated by IFN. With the exception of IFITM5, the genomic and protein sequence identities of the IFITM genes are high. Their protein structures are similar, each containing two transmembrane domains, one conserved intracellular loop and two extra-cellular terminals. As one of the IFITM family members, IFITM3 has been demonstrated to be pivotal in IFN signaling, as downregulating the expression of IFITM3 using small interfering RNA was observed to reduce the antiviral activities performed by IFN- $\gamma$ by $40-70 \%$ (2).

Endogenous IFITM3 may have important regulatory effects intracellularly. IFITM3 is involved in cellular development and differentiation (3). Previous studies have identified genetic variations or altered expression of IFITM3 that may be associated with immune diseases, such as viral infections (2) schizophrenia (4), autism $(5,6)$, inflammatory bowel disease (7) and cancer (8-10). The human HeLa cell line is one of the most widely used cell line in molecular biology for investigating gene functions $(11,12)$, and the endogenous expression of IFITM3 has been detected in HeLa cells previously (2). To investigate the global transcriptional profile when IFITM3 is downregulated, the present study used a knockdown (KD) approach and identified a series of altered transcripts when IFITM3 was downregulated in HeLa cells. Investigating alterations in the global transcriptional profile may improve current understanding of the molecular mechanism of the antimicrobial function of IFITM3.

\section{Materials and methods}

KD of endogenous IFITM3. HeLa cells (America Type Culture Collection, Manassas, VA, USA; cat. no. CRL-2266) at a density of $3-5 \times 10^{6}$ per T75 flask (Greiner Bio-One, Frickenhausen, Germany) were cultured in Dulbecco's modified Eagle's medium (DMEM)/15\% fetal bovine serum (FBS)/10 mM HEPES (Invitrogen; Thermo Fisher Scientific, Inc., Waltham, MA, USA) 1 day prior to lentiviral infection. Following culture, the IFITM3 short hairpin (sh)RNA lentivirus (Santa Cruz Biotechnology, Inc.; cat. no. sc-97053-V) 
or control shRNA lentivirus (Santa CruzBiotechnology, Inc.; cat. no. sc-108080), each with a multiplicity of infection of $50 \%$, was added to polybrene with a $8 \mu \mathrm{g} / \mathrm{ml}$ final concentration (Sigma-Aldrich; Thermo Fisher Scientific, Inc.; cat. no. S2667) to the cultures and incubated overnight at $37^{\circ} \mathrm{C}$. On the third day, selection medium (DMEM/15\%FBS/10 mM HEPES containing $50 \mu \mathrm{g} / \mathrm{ml}$ puromycin) was added for sorting of the stably infected cells. After 1 week, the adherent cells were digested with $0.25 \%$ trypsin and $0.02 \%$ EDTA, and resuspended for single cell culture at a density of $1.0 \times 10^{3}$ cells/well in 96-well plates, with the same selection medium as that described above, for monoclonal colony amplification.

Reverse transcription-polymerase chain reaction (RT-PCR) analysis. Cell selection was performed by adding puromycin to the cell culture medium, following which the resistant monoclonal colonies were identified. The efficiency of endogenous IFITM3 KD in the HeLa cells were confirmed by RT-PCR analysis. The re-cultured HeLa cells were harvested and RNA was extracted using a standard TRIzol procedure (Invitrogen; Thermo Fisher Scientific, Inc.; cat. no. 15596-018). The RNA was subjected to cDNA synthesis using M-MLV reverse transcriptase (Promega; Madison, WI, USA; cat. no. M170) in a $20 \mu 1$ liquid phase reaction, from which $1 \mu 1$ of cDNA was used for subsequent PCR amplification. The primers used as an internal control for RT-PCR to amplify human $18 \mathrm{~S}$ were as follows: Forward 5'-GGAAGGGCACCACCAGGAGT and reverse 5'-TGC AGCCCCGGACATCTAAG. The primers used for amplifying the IFITM3 and IFITM3-targeted RNAs via PCR analysis (Opticon ${ }^{\circledR}$ DNA engine; MJ Research, Waltham, MA, USA, cat. no. CFD3200) are listed in Table I. SYBR Premix Ex Taq II (Takara Biotechnology Co., Ltd. Dalian, China) were used for quantitative (q) PCR in a $25 \mu$ reaction volume with $95^{\circ} \mathrm{C}$ for $30 \mathrm{sec}$ followed by 40 cycles with each cycle consisting of $95^{\circ} \mathrm{C}$ for $5 \mathrm{sec}$ and $60^{\circ} \mathrm{C} 30 \mathrm{sec}$. Relative expression ratio of targeted genes were analyzed using the $2^{-\Delta \Delta C q}$ method (13) with $18 \mathrm{~S}$ as a reference gene.

Analyses of mRNA expression using oligonucleotide arrays. The RNA KD and control (CT) HeLa cells were cultured for mRNA extraction three times independently. The three RNA samples from the KD cells were mixed with equal quality, as were those from the CT cells. Microarray analysis was performed using a Human Whole Genome Oligo Microarray (Agilent Technologies, Inc., Santa Clara, CA, USA; cat. no. G4112A). According to the protocols of the Low RNA Input Linear Amplification and Labeling Kit Plus (Agilent Technologies; cat. no. 5184-3523), double-stranded cDNA was synthesized and applied as a template to label cRNA. Cy3 (scanned as red) was used to label the cRNA from the KD group from that of CT group. The ratio of fluorescence intensity for each probe $(\mathrm{KD} / \mathrm{CT})$ was determined to indicate the difference between the RNA-KD and CT cells. Certain transcripts identified as IFITM3-targeted were subjected to quantitative (q)PCR analysis to enable relative quantification. Gene Ontology (GO) enrichment analysis was performed according to the GO database (www.geneontology.org) to identify significant functional categories among differentially expressed genes. Furthermore, pathway analysis was performed using the Kyoto Encyclopedia of Genes and Genomes (www.genome.jp/kegg) and BioCarta (www.biocarta.com) pathway analysis programs. Each P-value was calculated with Fisher's exact test using the R-package, whereas each q-value was calculated with John Storey's method using the R-package (14).

\section{Results}

IFITM3-targeted transcripts. The transcriptional expression profiles of the endogenous IFITM3-KD and CT HeLa cells were investigated using a human Agilent GeneChip microarray platform. Using the 2-fold change as the cut-off, the Agilent microchip revealed 1,011 downregulated and 615 upregulated transcripts. It was noted that certain alterations gathered in gene families, including the histone (HIST), caveolae (CAV), pregnancy-specific $\beta$-1-glycoprotein (PSG), calmodulin (CALM), E twenty-six (ETS) and golgin (GOLG) families (Fig. 1).

Validation of IFITM3-targeted transcripts using qPCR analysis. Several IFITM3-targeted transcripts of the HIST family, including HIST cluster 1 (HIST1) H1a, HIST1 H1b, HIST1 H2aa, HIST1 H4j and HIST1 h4k, were further assessed using RT-qPCR analysis. In addition, certain additional transcripts, including mitogen-activated protein kinase 13 , myeloid differentiation primary response 88 , prostaglandin-endoperoxide synthase 2 , transmembrane emp24 protein transport domain containing 7, ubiquitin-conjugating enzyme E2 N, vitamin $\mathrm{D}$ receptor and thioredoxin interacting protein, were randomly selected for validation. The gene expression levels determined using RT-qPCR analysis appeared coincident with those of the microarray (Fig. 2).

Analysis of altered pathways. In the present study, when endogenous expression of IFITM3 in the HeLa cells was reduced, several genes in the antigen processing and presentation pathway appeared to be either upregulated or downregulated.

The IFITM3-downregulated targets were subjected to clustering pathway analysis, and the associated gene pathways (21 upregulated and 21 downregulated) are listed in Table II. Alterations of gene expression involving the complement cascades, antigen processing and presentation pathways are detailed independently in Fig. 3. It was found that the majority of the transcripts detected in the complement pathway exhibited a downregulatory trend, particularly transcripts of complement component 3 (C3), complement component $4 \mathrm{~b}$ (C4B) and complement component 5 (C5). In terms of the antigen processing and presentation pathway, transcripts of heat shock protein $90 \mathrm{kDa} \alpha$ class A member 1 , heat shock $70 \mathrm{kDa}$ protein $1 \mathrm{~A}$, heat shock $70 \mathrm{kDa}$ protein 1-like, heat shock $70 \mathrm{kDa}$ protein 2 , heat shock $70 \mathrm{kDa}$ protein 8 , nuclear transcription factor Y (NFY) $\alpha$ and NFY $\beta$ were upregulated, whereas the transcripts of heat shock $70 \mathrm{kDa}$ protein 5 , heat shock $70 \mathrm{kDa}$ protein 6 , regulatory factor X-associated protein, killer cell immunoglobulin-like receptor (KIR) three domains and long cytoplasmic tail 3, KIR two domains and short cytoplasmic tail 4, calreticulin 
Table I. Primers used for reverse transcription-quantitative polymerase chain reaction analysis.

\begin{tabular}{lll}
\hline Gene & \multicolumn{1}{c}{ Forward primer (5'-3') } & Reverse primer (5'-3') \\
\hline IFITM3 & ATGAATCACACTGTCCAAACCTTCT & CTATCCATAGGCCTGGAAGATCAG \\
VDUP1 & CGATAGTTTCGGGTCAGG & GATACATAAGTTCAAGGTCCAA \\
VDR & CAGGGTGGGATGGAGGAGAAG & TGGGTGGTGGAGTGAGAATAAGAA \\
UBE2N & AACTTTATTTAGACGCTGTAGATGG & AATGTTATTAGTGAGGGCTGTGAT \\
TMED7 & ATTGGATAGCCATCCTAGTCACT & GCTGGTCTTCAAACACCGTAA \\
PTGS2 & TGTCCCTTTACTTCATTCAGTGTTC & ATGACTCCTTCTCCGCAACA \\
PLCB4 & AAGCCTGCTGTAGTTGAGTTGC & CTTGACGAGTGTTATGCGTGTTT \\
MYD88 & GAATCCCTGTAGGAAATGGTGAAGC & AGGAAGTGGAATGGGCGGTGT \\
MAPK13 & GCCAAATCCTACATCCAGTCCCT 1 A1 & TCCAGCATCTTCTCCAGCAGGT \\
HIST1H4J & TCCGTGTCAGAGCTGATCGTG & GCGGCTGTTGTCTTCTCCAC \\
HIST1H4K & GATCCGGGACGCCGTGACCTAT & GGGACGCTCAACCACCGAAACC \\
HIST1H1B1 & TCCGGGACGCCGTGACCTATA & GGACGCTCAACCACCGAAACC \\
HIST1H2AA & CTTGCCACCATGTCGGAAACC & CCAGCTTAATGCGGCTGTTATTCTT \\
\hline
\end{tabular}

IFITM3, interferon inducible transmembrane protein 3; VDUP1; vitamin D3 upregulated protein 1; VDR, vitamin D receptor; UBE2N, ubiquitin-conjugating enzyme E2 N; TMED7, transmembrane emp24 protein transport domain containing 7; PTGS2, prostaglandin-endoperoxide synthase 2; PLCB4, phospholipase C $\beta 4$; MYD88, myeloid differentiation primary response 88; MAPK13, mitogen-activated protein kinase 13; HIST, histone.
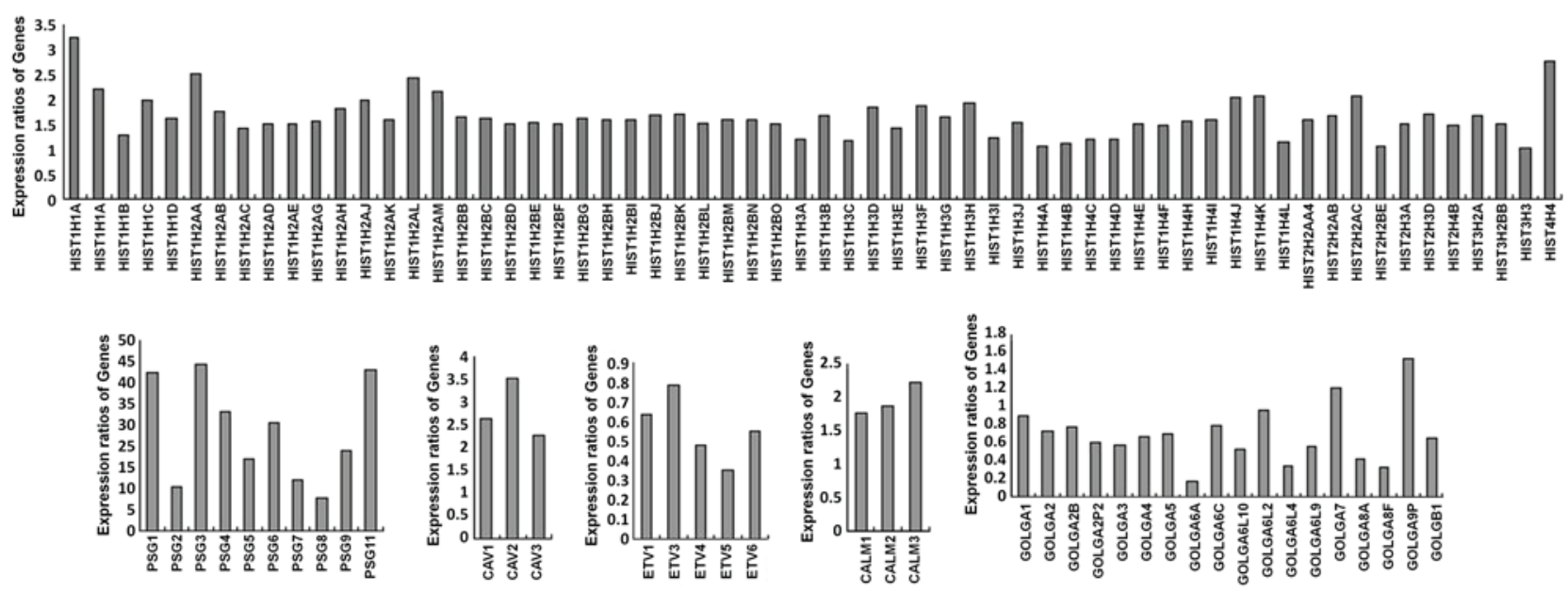

Figure 1. Gene families altered by interferon inducible transmembrane protein 3 knockdown. Expression ratios of altered levels of genes in HIST, CAV, PSG, CALM, ETV and GOLG families between IFITM3 knocked down cells and control cells were showed as columns. HIST, histone, CAV, caveolae; PSG, pregnancy-specific $\beta$-1-glycoprotein; CALM, calmodulin; ETV, ets variant; GOLG, golgin.

and major histocompatibility complex class II, DQ $\alpha 2$, were downregulated.

\section{Discussion}

Alterations in expression gathered in gene families. When IFITM3 was downregulated by shRNA, the HeLa cells showed an altered gene expression profile. The expression levels of hundreds of gene transcripts were altered and associated with multiple gene pathways. The differentially expressed profile obtained in the present study provided evidence that IFITM3 is involved in regulating a broad range of transcripts, and this is likely to result in different consequences in terms of the biological functions of cells. Of note, similar changes were found to be gathered in families.

It was found that the majority of gene transcripts in the HIST, CAV, PSG and CALM families, were upregulated. Histones are basic nuclear proteins, which are responsible for the nucleosome structure within the chromosomal fiber in eukaryotes. The expression of HIST genes is coupled temporally and functionally with DNA replication, and is controlled at the transcriptional and post-transcriptional levels (15). The PSG family belongs to a member of the immunoglobulin superfamily (16). Evidence shows that it is involved in modulation of the innate immune system (17). All the CALM family gene members (CALM1, CALM2 and 
Table II. Associated pathways with altered regulation.

\begin{tabular}{|c|c|c|c|}
\hline Pathway & Count & P-value & q-value \\
\hline \multicolumn{4}{|l|}{ Upregulated } \\
\hline Focal adhesion & 20 & $1.2 \mathrm{e}-15$ & $2.0 \mathrm{e}-13$ \\
\hline $\begin{array}{l}\text { Calcium signaling } \\
\text { pathway }\end{array}$ & 14 & $6.5 e-10$ & $1.1 \mathrm{e}-8$ \\
\hline $\begin{array}{l}\text { Regulation of actin } \\
\text { cytoskeleton }\end{array}$ & 13 & $4.9 \mathrm{e}-8$ & $5.1 \mathrm{e}-7$ \\
\hline Gap junction & 9 & $9.6 \mathrm{e}-8$ & $8.9 \mathrm{e}-7$ \\
\hline $\begin{array}{l}\text { MAPK signaling } \\
\text { pathway }\end{array}$ & 13 & 7.1e-7 & 0.0000048 \\
\hline Wnt signaling pathway & 10 & $7.1 \mathrm{e}-7$ & 0.0000048 \\
\hline Glioma & 7 & 0.0000013 & 0.0000078 \\
\hline Nitrogen metabolism & 5 & 0.0000015 & 0.0000090 \\
\hline $\begin{array}{l}\text { Cytokine-cytokine } \\
\text { receptor interaction }\end{array}$ & 12 & 0.0000026 & 0.000013 \\
\hline Melanogenesis & 8 & 0.0000029 & 0.000014 \\
\hline $\begin{array}{l}\text { Pathogenic Escherichia } \\
\text { coli infection }\end{array}$ & 6 & 0.0000068 & 0.000026 \\
\hline $\begin{array}{l}\text { ECM-receptor } \\
\text { interaction }\end{array}$ & 7 & 0.0000072 & 0.000026 \\
\hline $\begin{array}{l}\text { Antigen processing } \\
\text { and presentation }\end{array}$ & 7 & 0.000011 & 0.000034 \\
\hline Axon guidance & 8 & 0.000015 & 0.000047 \\
\hline $\begin{array}{l}\text { Complement and } \\
\text { coagulation cascades }\end{array}$ & 6 & 0.000026 & 0.000074 \\
\hline $\begin{array}{l}\text { Systemic lupus } \\
\text { erythematosus }\end{array}$ & 8 & 0.000032 & 0.000088 \\
\hline $\begin{array}{l}\text { Long-term } \\
\text { potentiation }\end{array}$ & 6 & 0.000041 & 0.00010 \\
\hline $\begin{array}{l}\text { B cell receptor } \\
\text { signaling pathway }\end{array}$ & 6 & 0.000041 & 0.00010 \\
\hline $\begin{array}{l}\text { Phosphatidylinositol } \\
\text { signaling system }\end{array}$ & 6 & 0.000045 & 0.00011 \\
\hline Prostate cancer & 6 & 0.00010 & 0.00023 \\
\hline \multicolumn{4}{|l|}{ Downregulated } \\
\hline $\begin{array}{l}\text { MAPK signaling } \\
\text { pathway }\end{array}$ & 19 & $4.4 \mathrm{e}-10$ & $9.1 \mathrm{e}-9$ \\
\hline $\begin{array}{l}\text { Arachidonic acid } \\
\text { metabolism }\end{array}$ & 9 & $1.5 \mathrm{e}-8$ & $1.5 \mathrm{e}-7$ \\
\hline $\begin{array}{l}\text { Glycine, serine and } \\
\text { threonine metabolism }\end{array}$ & 8 & $2.4 \mathrm{e}-8$ & $2.1 \mathrm{e}-7$ \\
\hline Long-term depression & 9 & $1.1 \mathrm{e}-7$ & $6.8 \mathrm{e}-7$ \\
\hline $\begin{array}{l}\text { Calcium signaling } \\
\text { pathway }\end{array}$ & 12 & 0.0000013 & 0.0000066 \\
\hline $\begin{array}{l}\text { Cytokine-cytokine } \\
\text { receptor interaction }\end{array}$ & 14 & 0.0000019 & 0.0000091 \\
\hline VEGF signaling pathway & 8 & 0.0000023 & 0.000010 \\
\hline $\begin{array}{l}\text { Cell adhesion } \\
\text { molecules }\end{array}$ & 10 & 0.0000031 & 0.000012 \\
\hline GnRH signaling pathway & 9 & 0.0000036 & 0.000014 \\
\hline Insulin signaling pathway & 10 & 0.0000040 & 0.000015 \\
\hline Nitrogen metabolism & 5 & 0.0000062 & 0.000022 \\
\hline $\begin{array}{l}\text { Aminoacyl-tRNA } \\
\text { biosynthesis }\end{array}$ & 6 & 0.0000062 & 0.000022 \\
\hline
\end{tabular}

Table II. Continued.

\begin{tabular}{lrcr}
\hline Pathway & Count & P-value & q-value \\
\hline $\begin{array}{l}\text { Linoleic acid } \\
\text { metabolism }\end{array}$ & 5 & 0.000020 & 0.000057 \\
$\begin{array}{l}\text { Histidine metabolism } \\
\text { Neuroactive ligand- }\end{array}$ & 5 & 0.000023 & 0.000065 \\
$\begin{array}{l}\text { receptor interaction } \\
\text { Antigen processing }\end{array}$ & 7 & 0.000038 & 0.00010 \\
$\begin{array}{l}\text { and presentation } \\
\text { Tryptophan } \\
\text { metabolism }\end{array}$ & 5 & 0.000012 & 0.00026 \\
$\begin{array}{l}\text { Complement and } \\
\text { coagulation cascades } \\
\text { Type II diabetes }\end{array}$ & 6 & 0.00013 & 0.00028 \\
mellitus & 5 & 0.00015 & 0.00031 \\
$\begin{array}{l}\text { Regulation of actin } \\
\text { cytoskeleton }\end{array}$ & 10 & 0.00020 & 0.00040 \\
\hline
\end{tabular}

MAPK, mitogen-activated protein kinase; ECM, extracellular matrix; VEGF, vascular endothelial growth factor; GnRh, gonadotropin-releasing hormone.

CALM3) encode an identical protein, calmodulin, which modulates a calcium-activated cadherin function. CALM members are considered to be involved in the intracellular invasion and colonization of human intestinal epithelial cells by Campylobacter jejuni in vitro. CALM1 was found to exist close to a risk locus of $C$. jejuni colonization in the avian intestine in a population-based genome-wide association study (18).

By contrast, the majority of the gene transcripts in the ETS family and GOLG family were downregulated. The ETS proteins are transcription factors; they regulate several target genes, which modulate cellular functions, including growth, apoptosis, development, differentiation and oncogenic transformation (19). The GOLG family of proteins localize to the Golgi, and appear to be involved in membrane traffic and Golgi structure; individual golgins are found in different locations in the Golgi stack, and are typically anchored to the membrane at their carboxyl termini by a transmembrane domain or by binding a small GTPase (20). Although these altered gene families require further validation to confirm their association with IFITM3, the results of the present study provide insight for an improved understanding of the molecular functions of IFITM3.

Potential role of IFITM against microorganisms. Previously, IFITM3 has been found to inhibit the replication of human immunodeficiency virus-1 (21). In addition, IFITMs, particularly IFITM3, have been confirmed to inhibit viral infections, by influenza A virus, flaviviruses (dengue virus, West Nile virus and hepatitis C) and filoviruses (Ebola virus and Marburg virus) (22-24). In our previous study, a functional polymorphism of IFITM3 was found to contribute to tuberculosis susceptibility (25). Thus, IFITM3 may limit microorganism infection by adjusting the host immune 
Table III. Genes detected in the complement pathway.

\begin{tabular}{|c|c|c|c|c|c|}
\hline Gene ID & Symbol & Full name & Probe ID & Systematic name & Fold change \\
\hline 715 & $\mathrm{C} 1 \mathrm{R}$ & $\begin{array}{l}\text { Complement component } \\
1, \mathrm{r} \text { subcomponent }\end{array}$ & A_23_P125423 & NM_001733 & 1.32 \\
\hline 716 & C1S & $\begin{array}{l}\text { Complement component } \\
1, \text { s subcomponent }\end{array}$ & A_23_P2492 & NM_001734 & 2.1 \\
\hline 718 & $\mathrm{C} 3$ & Complement component 3 & A_23_P101407 & NM_000064 & 0.42 \\
\hline 721 & $\mathrm{C} 4 \mathrm{~B}$ & Complement component 4B & A_23_P42282 & NM_001002029 & 0.41 \\
\hline 727 & $\mathrm{C} 5$ & Complement component 5 & A_23_P71855 & NM_001735 & 0.3 \\
\hline 3627 & $\mathrm{C} 7$ & Complement component 7 & A_23_P213857 & NM_000587 & 0.83 \\
\hline 733 & $\mathrm{C} 8 \mathrm{G}$ & Complement component $8 \mathrm{G}$ & A_23_P20713 & NM_000606 & 0.77 \\
\hline 629 & CFB & Complement factor B & A_23_P156687 & NM_001710 & 0.54 \\
\hline 8518 & CFD & Complement factor D & A_23_P119562 & NM_001928 & 0.72 \\
\hline 10747 & MASP2 & $\begin{array}{l}\text { Mannan-binding lectin } \\
\text { serine peptidase } 2\end{array}$ & A_23_P301971 & NM_139208 & 1.27 \\
\hline 719 & C3AR1 & $\begin{array}{l}\text { Complement component } \\
\text { 3a receptor } 1\end{array}$ & A_23_P2431 & NM_004054 & 0.64 \\
\hline 728 & C5AR1 & $\begin{array}{l}\text { Complement component } \\
\text { 5a receptor } 1\end{array}$ & A_23_P153562 & NM_001736 & 0.69 \\
\hline 3689 & ITGB2 & $\begin{array}{l}\text { Complement component } 3 \\
\text { receptor } 3 \text { and } 4 \text { subunit }\end{array}$ & A_23_P329573 & NM_000211 & 0.64 \\
\hline
\end{tabular}

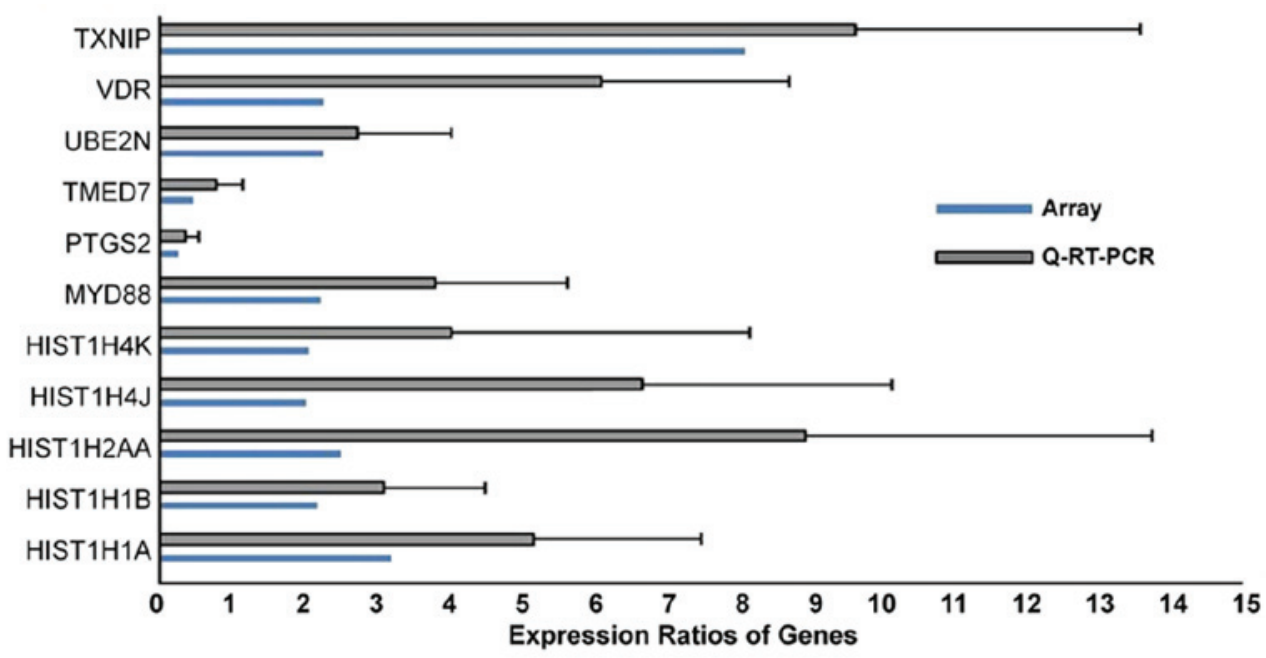

Figure 2. Reverse transcription-quantitative polymerase chain reaction analysis validation. TXNIP, thioredoxin-interacting protein; VDR, vitamin D receptor; UBE2N, ubiquitin-conjugating enzyme E2 N, TMED7, transmembrane emp24 protein transport domain containing 7; PTGS2, prostaglandin-endoperoxide synthase 2; MYD88, myeloid differentiation primary response 88; HIST, histone.

ability. However, the precise mechanisms remain to be fully elucidated.

As is known, the control of pathogen infections is critically dependent on the recognition and elimination of infected cells. As a biological process of the innate immune system, antigen processing prepares antigens for presentation to specific cells of the immune system.

According to the clustering pathway analysis performed in the present study, when the endogenous expression of IFITM3 in HeLa cells was reduced, 21 upregulated and 21 downregulated pathways were identified. Several genes in the antigen processing and presentation pathway appeared to be either upregulated or downregulated. Of note, the majority of the components in complement signaling were downregulated, particularly C3, C4b, and C5 (Table III). Among these altered complement molecules, C5 showed the most marked reduction. As a feature of the innate immune system, the complement system assists in clearing pathogens from an organism. The complement system can be activated by the classical complement pathway, the alternative complement pathway or the mannose-binding lectin pathway $(26,27)$. In all three pathways, a C3-convertase cleaves and activates $\mathrm{C} 3$, creating $\mathrm{C} 3 \mathrm{a}$ and $\mathrm{C} 3 \mathrm{~b}$, and causing a 


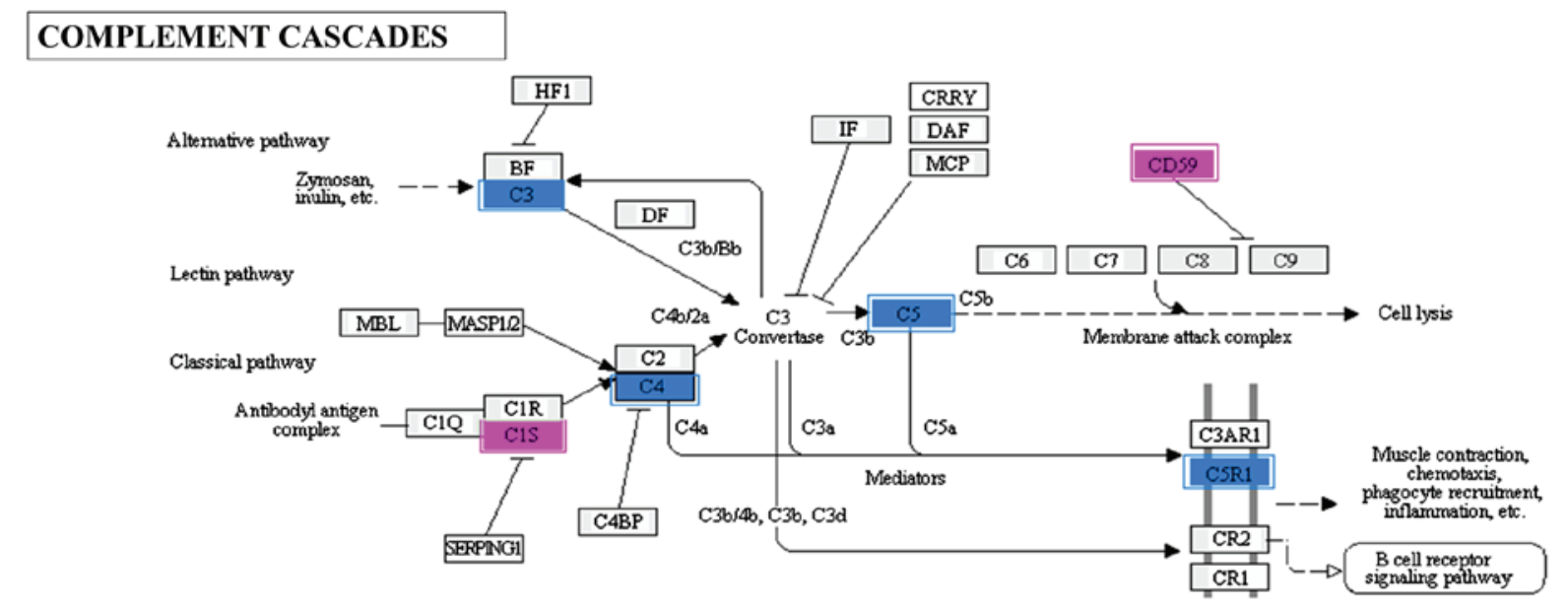

\section{ANTIGEN PROCESSING AND PRESENTATION}

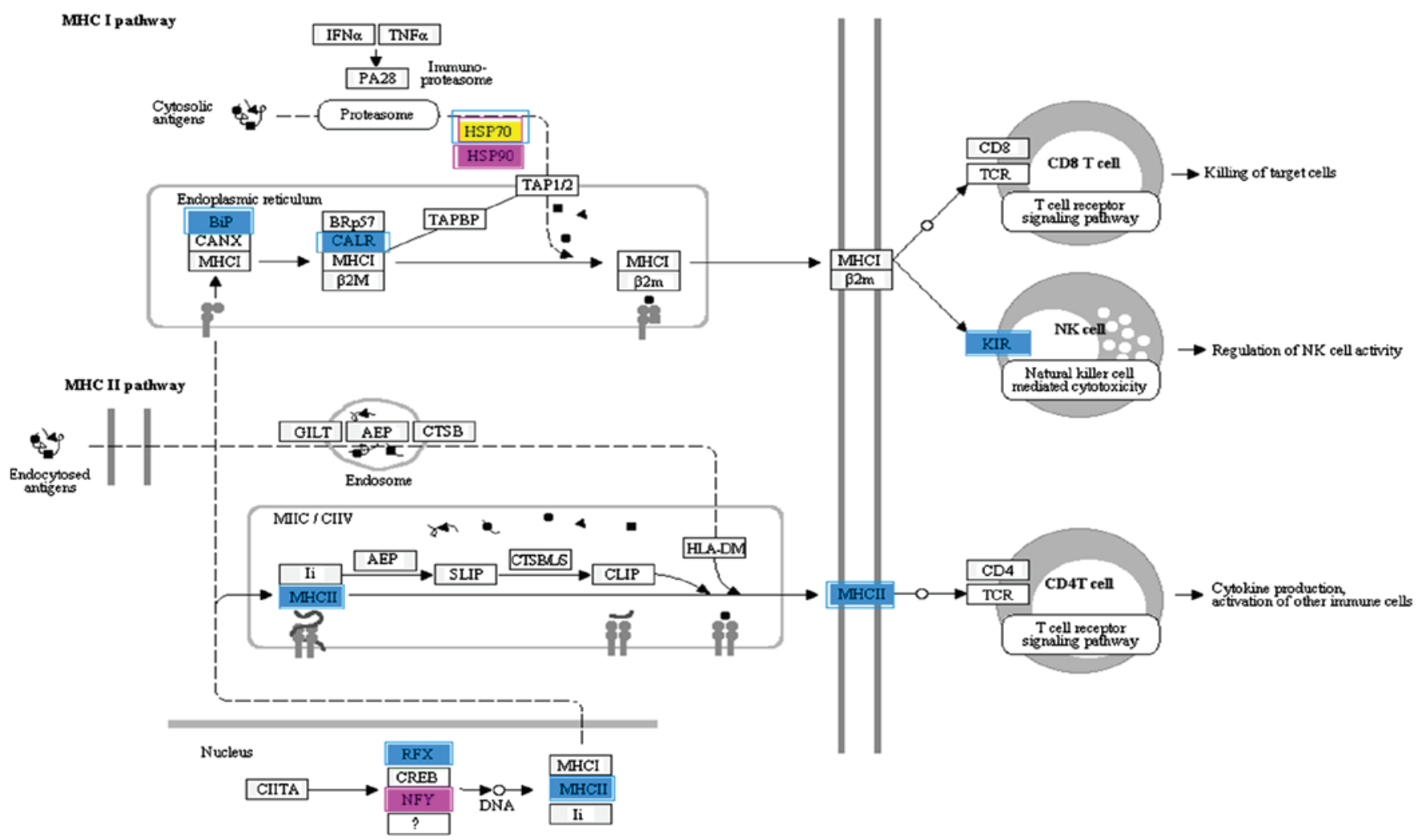

Figure 3. Affected gene pathways associated with interferon inducible transmembrane protein 3 knockdown. Purple, upregulated; yellow, upregulated and downregulated; blue, downregulated.

cascade of further cleavage and activation events. C3b binds to the surface of pathogens, leading to increased internalization by phagocytic cells through opsonization. Individuals with $\mathrm{C} 3$ deficiency are susceptible to bacterial infection (28). Increased levels of $\mathrm{C} 3 \mathrm{a}$ have been found in the bronchoalveolar lavage fluid (BALF) of mice infected with the pathogenic avian influenza, H5N1 (29). C4b is the basic form of complement factor 4, which is a member of the classical activation pathway. Extensive deposition of its fragment has been found in the lungs in cases of influenza-associated mortality (30). C5 is comprised of $\alpha$ and $\beta$ polypeptide chains (C5a and C5b), which are linked by a disulfide bridge. $\mathrm{C} 5 \mathrm{a}$ is an important chemotactic cleavage product, assisting in the recruitment of inflammatory cells.
C5b initiates the membrane attack pathway, by forming in the membrane attack complex, which is the cytolytic end product of the complement cascade and forms a transmembrane channel to cause osmotic lysis of the target cell. Kupffer cells and other macrophage cell types assist in clearing complement-coated pathogens. Individuals with C5 mutation show a propensity for severe recurrent infections. Increased levels of $\mathrm{C} 5 \mathrm{a}$ have been found in the BALF of mice infected with H5N1 and influenza virus $A(29,31)$.

The results of the present study suggested that sufficient expression of IFITM3 appeared to be pivotal for the recognition and elimination of infected cells by altering the transcription of genes involving the complement cascade. 
As a member of the IFITM protein family, IFITM3 is involved in various biological processes. In the present study, the use of endogenous IFITM3-KD provided information regarding global gene expression alterations, and assisted in identifying the IFITM3-targeted transcripts and pathways. The results of the present study may enable more detailed investigation of the biological functions of IFITM3 in the future.

\section{Acknowledgements}

This study was supported by grants from the National Natural Science Foundation of China (grant nos. 81301403 and 81071315) and the Basic-Clinical Research Cooperation Grant from Capital Medical University (grant no. 11JL53).

\section{References}

1. Siegrist F, Ebeling $M$ and Certa U: The small interferon-induced transmembrane genes and proteins. J Interferon Cytokine Res 31: 183-197, 2011.

2. Brass AL, Huang IC, Benita Y, John SP, Krishnan MN, Feeley EM, Ryan BJ, Weyer JL, van der Weyden L, Fikrig E, et al: The IFITM proteins mediate cellular resistance to influenza A H1N1 virus, West Nile virus, and dengue virus. Cell 139: 1243-1254, 2009.

3. Tanaka SS, Yamaguchi YL, Tsoi B, Lickert H and Tam PP: IFITM/Mil/fragilis family proteins IFITM1 and IFITM3 play distinct roles in mouse primordial germ cell homing and repulsion. Dev Cell 9: 745-756, 2005.

4. Saetre P, Emilsson L, Axelsson E, Kreuger J, Lindholm E and Jazin E: Inflammation-related genes up-regulated in schizophrenia brains. BMC Psychiatry 7: 46, 2007.

5. Garbett K, Ebert PJ, Mitchell A, Lintas C, Manzi B, Mirnics K and Persico AM: Immune transcriptome alterations in the temporal cortex of subjects with autism. Neurobiol Dis 30: 303-311, 2008.

6. Ghahramani Seno MM, Hu P, Gwadry FG, Pinto D, Marshall CR, Casallo G and Scherer SW: Gene and miRNA expression profiles in autism spectrum disorders. Brain Res 1380: 85-97, 2011.

7. Seo GS, Lee JK, Yu JI, Yun KJ, Chae SC and Choi SC: Identification of the polymorphisms in IFITM3 gene and their association in a Korean population with ulcerative colitis. Exp Mol Med 42: 99-104, 2010.

8. Hisamatsu T, Watanabe M, Ogata H, Ezaki T, Hozawa S, Ishii H, Kanai $\mathrm{T}$ and Hibi T: Interferon-inducible gene family 1-8U expression in colitis-associated colon cancer and severely inflamed mucosa in ulcerative colitis. Cancer Res 59: 5927-5931, 1999.

9. Fan J, Peng Z, Zhou C, Qiu G, Tang H, Sun Y, Wang X, Li Q, Le $\mathrm{X}$ and Xie K: Gene-expression profiling in Chinese patients with colon cancer by coupling experimental and bioinformatic genomewide gene-expression analyses: Identification and validation of IFITM3 as a biomarker of early colon carcinogenesis Cancer 113: 266-275, 2008

10. Andreu P, Colnot S, Godard C, Laurent-Puig P, Lamarque D, Kahn A, Perret C and Romagnolo B: Identification of the IFITM family as a new molecular marker in human colorectal tumors. Cancer Res 66: 1949-1955, 2006.

11. Shen L, Liu Q, Ni J and Hong G: A proteomic investigation into the human cervical cancer cell line HeLa treated with dicitratoytterbium (III) complex. Chem Biol Interact 181: 455-462, 2009.

12. Zhang J, Timoney PJ, MacLachlan NJ, McCollum WH and Balasuriya UB: Persistent equine arteritis virus infection in HeLa cells. J Virol 82: 8456-8464, 2008.

13. Livak KJ and Schmittgen TD: Analysis of relative gene expression data using real-time quantitative PCR and the 2(-Delta Delta C(T)) method. Methods 25: 402-408, 2001.
14. Storey JD, Taylor JE and Siegmund D: Strong control, conservative point estimation and simultaneous conservative consistency of false discovery rates: A unified approach. J R Statist Soc B 66: 187-205, 2004.

15. Happel N and Doenecke D: Histone H1 and its isoforms: Contribution to chromatin structure and function. Gene 431: 1-12, 2009.

16. Khan WN, Teglund S, Bremer K and Hammarström S: The pregnancy-specific glycoprotein family of the immunoglobulin superfamily: Identification of new members and estimation of family size. Genomics 12: 780-787, 1992.

17. Snyder SK, Wessner DH, Wessells JL, Waterhouse RM, Wahl LM, Zimmermann W and Dveksler GS: Pregnancy-specific glycoproteins function as immunomodulators by inducing secretion of IL-10, IL-6 and TGF-beta1 by human monocytes. Am J Reprod Immunol 45: 205-216, 2001.

18. Connell S, Meade KG, Allan B, Lloyd AT, Downing T, O'Farrelly C and Bradley DG: Genome-wide association analysis of avian resistance to Campylobacter jejuni colonization identifies risk locus spanning the CDH13 gene. G3 (Bethesda) 3: 881-890, 2013.

19. Oikawa T and Yamada T: Molecular biology of the Ets family of transcription factors. Gene 303: 11-34, 2003.

20. Munro S: The golgin coiled-coil proteins of the Golgi apparatus. Cold Spring Harb Perspect Biol 3: pii: a005256, 2011.

21. Lu J, Pan Q, Rong L, He W, Liu SL and Liang C: The IFITM proteins inhibit HIV-1 infection. J Virol 85: 2126-2137, 2011.

22. Yao L, Dong H, Zhu H, Nelson D, Liu C, Lambiase L and Li X: Identification of the IFITM3 gene as an inhibitor of hepatitis $\mathrm{C}$ viral translation in a stable STAT1 cell line. J Viral Hepat 18: e523-e529, 2011.

23. Huang IC, Bailey CC, Weyer JL, Radoshitzky SR, Becker MM, Chiang JJ, Brass AL, Ahmed AA, Chi X, Dong L, et al: Distinct patterns of IFITM-mediated restriction of filoviruses, SARS coronavirus, and influenza A virus. PLoS Pathog 7: e1001258, 2011.

24. Feeley EM, Sims JS, John SP, Chin CR, Pertel T, Chen LM, Gaiha GD, Ryan BJ, Donis RO, Elledge SJ and Brass AL: IFITM3 inhibits influenza A virus infection by preventing cytosolic entry. PLoS Pathog 7: e1002337, 2011.

25. Shen C, Wu XR, Jiao WW, Sun L, Feng WX, Xiao J, Miao Q, Liu F, Yin QQ, Zhang CG, et al: A functional promoter polymorphism of IFITM3 is associated with susceptibility to pediatric tuberculosis in Han Chinese population. PLoS One 8: e67816, 2013.

26. Janeway CA Jr, Travers P, Walport M and Shlomchik MJ: Immunobiology: The complement system and innate immunity. 5th edition. Garland Science, New York, NY. ISBN 0-815321, 2001-3642-X, 2001.

27. Abbas AK, Lichtman AH and Pillai S: Cellular and Molecular Immunology. 6th edition. Elsevier, Philadelphia, PA. pp. 272-288, 2010.

28. Miller EC, Chase NM, Densen P, Hintermeyer MK, Casper JT and Atkinson JP: Autoantibody stabilization of the classical pathway $\mathrm{C} 3$ convertase leading to $\mathrm{C} 3$ deficiency and Neisserial sepsis: C4 nephritic factor revisited. Clin Immunol 145: 241-250, 2012.

29. O'Brien KB, Morrison TE, Dundore DY, Heise MT and Schultz-Cherry S: A protective role for complement C3 protein during pandemic $2009 \mathrm{H} 1 \mathrm{~N} 1$ and H5N1 influenza A virus infection. PLoS One 6: e17377, 2011.

30. Monsalvo AC, Batalle JP, Lopez MF, Krause JC, Klemenc J, Hernandez JZ, Maskin B, Bugna J, Rubinstein C, Aguilar L, et al: Severe pandemic 2009 H1N1 influenza disease due to pathogenic immune complexes. Nat Med 17: 195-199, 2011.

31. Garcia CC, Weston-Davies W, Russo RC, Tavares LP, Rachid MA, Alves-Filho JC, Machado AV, Ryffel B, Nunn MA and Teixeira MM: Complement $\mathrm{C} 5$ activation during influenza $\mathrm{A}$ infection in mice contributes to neutrophil recruitment and lung injury. PLoS One 8: e64443, 2013. 